\title{
Who provides gastrointestinal endoscopy in Canada?
}

\author{
Robert J Hilsden MD PhD FRCPC ${ }^{1}$, Joshua Tepper MD CFPC ${ }^{2}$, \\ Paul Moayyedi FRCP PhD ${ }^{3}$, Linda Rabeneck MD MPH FRCPC ${ }^{4}$
}

RJ Hilsden, J Tepper, P Moayyedi, L Rabeneck. Who provides gastrointestinal endoscopy in Canada? Can J Gastroenterol 2007;21(12):843-846.

PURPOSE: To determine who provides gastrointestinal endoscopy in Canada and to understand provincial and regional differences in endoscopy providers.

METHODS: Aggregate physician sociodemographic and activity data for 2002 were obtained from the Canadian Institute of Health Information's National Physician Database. Physicians were classified as gastroenterologists, general surgeons and others.

RESULTS: In 2002, 1444 physicians, including 735 surgeons, 551 gastroenterologists and 158 others, performed at least 100 colonoscopies or 100 gastroscopies. Gastroenterologists performed $53 \%$ of all colonoscopies and 59\% of all gastroscopies. Gastroenterologists were the primary providers of colonoscopies in large urban areas, whereas surgeons were the primary providers in smaller urban and rural areas. An average of 317 colonoscopies were performed by surgeons, 516 by gastroenterologists and 203 by other physicians. The proportion of surgeon colonoscopists in each province ranged from $47 \%$ to $71 \%$.

CONCLUSIONS: Surgeons and gastroenterologists are the major providers of gastrointestinal endoscopy in Canada, but the distribution of these providers among provinces and urban and rural areas varies. Although surgeon endoscopists are more numerous, on average, they perform fewer procedures annually than internists.

Key Words: Canada; Gastrointestinal endoscopy; Health manpower

\section{Qui effectue les endoscopies gastro- intestinales au Canada?}

\begin{abstract}
BUT : Déterminer qui effectue les endoscopies gastro-intestinales au Canada et comprendre les différences entre les provinces et les régions pour ce qui est des dispensateurs d'endoscopies.

MÉTHODES : Des données regroupées sur les caractéristiques sociodémographiques et les activités des médecins pour l'année 2002 ont été obtenues à partir de la base de données nationale sur les médecins de l'Institut canadien d'information sur la santé. Les médecins étaient classés selon qu'ils étaient gastro-entérologues, chirurgiens généraux ou autres. RÉSULTATS : En 2002, 1444 médecins, dont 735 chirurgiens, 551 gastro-entérologues et 158 autres ont effectué au moins 100 colonoscopies ou 100 gastroscopies. Les gastro-entérologues ont réalisé $53 \%$ de toutes les colonoscopies et $59 \%$ de toutes les gastroscopies. Les gastroentérologues ont été les principaux dispensateurs de colonoscopies dans les grandes régions urbaines, tandis que les chirurgiens en ont été les principaux dispensateurs dans les agglomérations plus petites et les régions rurales. En moyenne, 317 colonoscopies ont été effectuées par des chirurgiens, 516 par des gastro-entérologues et 203 par d'autres médecins. La proportion de colonoscopistes chirurgiens dans chaque province a varié de $47 \%$ à $71 \%$.

CONCLUSIONS : Les chirurgiens et les gastro-entérologues forment la majeure partie des dispensateurs d'endoscopies gastro-intestinales au Canada, mais la distribution de ces dispensateurs varie selon les provinces et selon qu'on se trouve en région urbaine ou rurale. Si les endoscopistes chirurgiens ont été plus nombreux, en moyenne, ils ont réalisé un moins grand nombre d'interventions annuellement que les internistes.
\end{abstract}

Flexible endoscopes were first developed in the 1960s to allow examination of the upper and lower gastrointestinal (GI) tract. Forty years later, these tests are widely available and have assumed a preeminent role in the diagnosis and treatment of disorders of the esophagus, stomach, duodenum, terminal ileum and colon. The use of these tests, especially colonoscopy, has dramatically increased in the past decade $(1,2)$. Ongoing growth in the use of colonoscopy will be driven by an aging population and increased screening for colorectal cancer. Colonoscopy plays a pivotal role in screening for colorectal cancer. It is the preferred diagnostic test following a positive screening test, such as the fecal occult blood test (FOBT) (3). However, colonoscopy is also used as a primary screening test, even for individuals at average risk for colorectal cancer. A practice audit of 111 Canadian endoscopists showed that $75 \%$ of endoscopists performed colonoscopies for colorectal cancer screening in average risk individuals (D Leddin, personal communication).
Organized, population-based colorectal cancer screening programs may soon be developed in several jurisdictions, which may place a significant burden on available endoscopy resources.

There is limited information on GI endoscopy resources in Canada, and no comprehensive registry of endoscopists exists. GI endoscopy is provided by a variety of physicians, including general internists, general surgeons, gastroenterologists, colorectal surgeons and family physicians. In the absence of a clear description of who provides endoscopy in Canada, the current endoscopic workforce is uncertain, and it is not possible to anticipate the impact of future demand on endoscopic capacity and availability that will be caused by anticipated changes in clinical practice and cancer screening.

The purpose of the present study was to determine who provides GI endoscopy in Canada, and to understand provincial and regional differences in endoscopy providers. The main focus was on colonoscopy, because colorectal cancer screening

${ }^{1}$ Departments of Medicine $\mathcal{E}^{2}$ Community Health Sciences, University of Calgary, Calgary, Alberta; ${ }^{2}$ Health Human Resource Strategy Division,

Ottawa; ${ }^{3}$ Department of Medicine, Division of Gastroenterology, McMaster University Medical Centre, Hamilton; ${ }^{4}$ Institute for Clinical

Evaluative Sciences, University of Toronto, Toronto, Ontario

Correspondence: Dr Robert J Hilsden, 3330 Hospital Drive Northwest, Calgary, Alberta T2N 4N1. Telephone 403-210-9355,

fax 403-283-6171,e-mail rhilsden@ucalgary.ca

Received for publication March 14, 2007. Accepted May 4, 2007 
TABLE 1

Physicians performing 100 or more colonoscopies or gastroscopies in Canada in 2002

\begin{tabular}{lccc}
\hline Physician type & $\begin{array}{c}\text { Physicians, } \\
\mathbf{n}\end{array}$ & $\begin{array}{c}\text { Colonoscopies, } \\
\mathbf{n ~ ( \% )}\end{array}$ & $\begin{array}{c}\text { Gastroscopies, } \\
\mathbf{n}(\%)\end{array}$ \\
\hline Surgeon & 735 & $229,226(44)$ & $108,418(28)$ \\
Internal medicine & 551 & $277,730(53)$ & $231,935(59)$ \\
Other & 158 & $16,268(3)$ & $52,215(13)$ \\
Total & 1444 & $523,224(100)$ & $392,568(100)$ \\
\hline
\end{tabular}

TABLE 2

Colonoscopies performed nationally, by physician type and census geographic area in Canada in 2002: Number of colonoscopies (proportion in each census area)

\begin{tabular}{lccc}
\hline $\begin{array}{l}\text { Physician } \\
\text { type }\end{array}$ & $\begin{array}{c}\text { Census } \\
\text { metropolitan } \\
\text { area, } \mathbf{n}(\%)\end{array}$ & $\begin{array}{c}\text { Census } \\
\text { agglomeration, } \\
\mathbf{n ~ ( \% )}\end{array}$ & $\begin{array}{c}\text { Other area, } \\
\mathbf{n}(\%)\end{array}$ \\
\hline Surgeon & $109,262(33)$ & $83,283(67)$ & $36,681(54)$ \\
Internal medicine & $213,360(65)$ & $37,520(30)$ & $26,850(39)$ \\
Other & $7372(2)$ & $4340(3)$ & $4556(7)$ \\
\hline
\end{tabular}

is the most apparent and imminent threat to timely access to endoscopy. The project was initiated and supported by the Canadian Association of Gastroenterology (CAG) to support the development of a human resource plan for gastroenterology in Canada (4).

\section{METHODS}

The National Physician Database (NPDB) provides information on the demographic characteristics of physicians and their level of activity within Canada (5). All provinces and territories submit quarterly data to the Canadian Institute of Health Information (CIHI), the organization that maintains the NPDB. CIHI receives sociodemographic information on all physicians who are registered with a provincial or territorial medical care plan and have a practice located in the province or territory. Activity data are based on service and payment data for individual physicians.

Aggregate physician sociodemographic and activity information was obtained for 2002 from the NPDB on all physicians who performed at least 100 colonoscopies or 100 gastroscopies. Sociodemographic data obtained included age group, sex, specialty, province or territory of practice and census area of practice. Within the NPDB, gastroenterologists are not recorded as a distinct specialty but are classified as internal medicine specialists. Similarly, colorectal surgeons are classified as general surgeons. For the present study, physicians were classified into the following groups: gastroenterologists, general surgeons and others. A gastroenterologist was defined as an internist performing at least 100 gastroscopies or 100 colonoscopies in one year. Those in the 'other' category included family physicians and other defined specialties, such as otolaryngologists and thoracic surgeons. For the census area of practice, three categories were possible: census metropolitan area (CMA), census agglomeration (CA) and other areas (6). Statistics Canada defines a CMA as a very large urban area with a population of at least 100,000 , together with adjacent urban and rural areas. A CA is defined as a large urban area with a population of at least 10,000, together with adjacent urban and rural areas. All other rural and small urban areas
TABLE 3

Gastroscopies performed nationally, by physician type and census geographic area in Canada in 2002: Number of gastroscopies (proportion in each census area)

\begin{tabular}{lccc}
\hline $\begin{array}{l}\text { Physician } \\
\text { type }\end{array}$ & $\begin{array}{c}\text { Census } \\
\text { metropolitan } \\
\text { area, } \mathbf{n}(\%)\end{array}$ & $\begin{array}{c}\text { Census } \\
\text { agglomeration, } \\
\mathbf{n}(\%)\end{array}$ & $\begin{array}{c}\text { Other area, } \\
\mathbf{n}(\%)\end{array}$ \\
\hline Surgeon & $36,853(15)$ & $48,329(51)$ & $23,236(42)$ \\
Internal medicine & $171,279(71)$ & $33,001(35)$ & $27,655(50)$ \\
Other & $33,361(14)$ & $13,918(15)$ & $4936(9)$ \\
\hline
\end{tabular}

were classified as 'other areas'. Activity data obtained included the total number of colonoscopies and gastroscopies performed by groups of physicians, as categorized by their sociodemographic characteristics.

As a measure of the workforce, the number of physicians who were providing endoscopy services was determined for Canada as a whole, for each province and by census area. Standard methods for determining full-time equivalent physicians (7) were not used to estimate physician supply because endoscopy is performed by different types of physicians, such as gastroenterologists and general surgeons, and the number of endoscopies performed by those different groups was expected to differ. Therefore, a full-time equivalent general surgeon would not be likely to provide the same amount of endoscopy services as a full-time equivalent gastroenterologist.

Summary tables were constructed using the NPDB data to describe providers of endoscopy services in Canada at a national, provincial and census area level. Because an individual physician may have practised in more than one province in 2002, the national total number of physicians providing endoscopies was less than the sum of the number of physicians providing endoscopies in each province. Statistics Canada's postcensal provincial population estimates were used to estimate the number of colonoscopists per 100,000 population in Canada and each province (8).

\section{RESULTS}

In 2002, 1444 physicians performed at least 100 colonoscopies or 100 gastroscopies in Canada. Gastroenterologists provided $53 \%$ of colonoscopies and 59\% of gastroscopies (Table 1). Gastroenterologists were also the primary endoscopy providers in large urban areas (CMAs). However, they played a smaller role in smaller urban (CAs) and rural areas (other areas) where surgeons were the main providers (Tables 2 and 3 ).

For those physicians who performed colonoscopy, the average number of colonoscopies performed in 2002 was 317 by surgeons, 516 by gastroenterologists and 203 by others. For surgeons and gastroenterologists, the annual colonoscopy volume was greatest for those working in large urban centres. For example, on average, gastroenterologists in large urban areas performed 547 colonoscopies, compared with 441 by those in small urban areas and 426 by those in more rural areas. The lowest annual procedure volume for 'other' physicians was also seen for those working in rural areas $(n=147)$, but the highest volume $(n=255)$ was seen for those in small urban areas.

Of the 1444 physicians shown in Table 1, 1291 (89\%) performed at least 100 colonoscopies. The distribution of those colonoscopy providers across Canada is shown in Table 4. The proportion of colonoscopists in each province who were general surgeons ranged from $47 \%$ to $71 \%$. 


\section{DISCUSSION}

The present study has shown that gastroenterologists and surgeons performed over $97 \%$ of all colonoscopies and $87 \%$ of all gastroscopies in Canada in 2002. Gastroenterologists were the major providers of colonoscopies in large urban areas, but in rural and smaller urban areas, surgeons were key providers. The number of colonoscopy providers per 100,000 population varies between provinces, from a low of 3.3 providers per 100,000 people in Alberta to a high of 5.4 providers per 100,000 people in the Atlantic provinces. However, because the endoscopy volume of providers varied dramatically, these provider to population ratios may be misleading. For example, gastroenterologists who, on average, perform more colonoscopies each year than other groups, comprise a larger proportion of all providers in Alberta than in Atlantic provinces.

To fully understand the implications of these findings, it is best to place the data into the clinical context of increasing colorectal cancer screening. The advent of population-based colorectal cancer screening programs would require timely access to high-quality and safe colonoscopy.

Screening for colorectal cancer has been recommended by several groups in Canada and, to date, three provinces (Ontario, Manitoba and Alberta) have announced plans to implement provincial screening programs (9-11). The National Committee on Colorectal Cancer Screening estimated that the first year of a biennial FOBT screening program would result in a $15 \%$ increase in the number of colonoscopies performed (12). An annual FOBT program could double this anticipated increase. The ability of current endoscopy resources to absorb this increase is uncertain, especially in provinces with a low number of colonoscopists per 100,000 population. The data in the present paper provide provincial organizations that are planning screening programs with information on local endoscopy resources to assist in planning and to help in understanding the potential impact of a mass screening program. However, before instituting a screening program within a given province, a dedicated colonoscopy workforce and facility assessment are required to ensure that adequate resources are available, considering the availability of resources not only in large metropolitan areas but also in rural areas.

There is no evidence on what the optimum number of endoscopists per 100,000 population should be. We have previously reported that Canada has fewer gastroenterologists per 100,000 population than the United States, France or Australia (13), but similar comparisons for endoscopists as a whole are not currently available. CAG's Practice Audit in Gastroenterology IV Program demonstrated long waiting times for GI care in Canada (14). These data suggest that human resources are inadequate, because waiting times were prolonged for both initial consultation and endoscopy. The Canadian Medical Association's 2003 Physician Resource Questionnaire (15) documented that medical and surgical specialists were averaging $54.5 \mathrm{~h}$ and $57.6 \mathrm{~h}$ of work per week, respectively. The data from the CAG and the Canadian Medical Association suggest that merely increasing endoscopy facility resources will not be adequate to meet the colonoscopy demand resulting from provincial screening programs.

In general, Canadian specialist physicians do not control the number of funded training positions in their discipline. Furthermore, no mechanism exists to ensure that the training
TABLE 4

\begin{tabular}{|c|c|c|c|c|c|}
\hline Region & $\begin{array}{c}\text { General } \\
\text { surgeon, } \\
\text { n (\%) }\end{array}$ & $\begin{array}{c}\text { Internist, } \\
\text { n (\%) }\end{array}$ & $\begin{array}{l}\text { Other, } \\
\text { n (\%) }\end{array}$ & $\begin{array}{c}\text { Total, } \\
\text { n }\end{array}$ & $\begin{array}{c}\text { Per } 100,000 \\
\text { population, } \\
n\end{array}$ \\
\hline British Columbia & $87(57)$ & $57(37)$ & $9(6)$ & 153 & 3.7 \\
\hline Alberta & $48(47)$ & $42(41)$ & $12(12)$ & 102 & 3.3 \\
\hline $\begin{array}{l}\text { Saskatchewan } \\
\text { and Manitoba }\end{array}$ & $69(71)$ & $24(25)$ & $4(4)$ & 97 & 4.5 \\
\hline Ontario & $312(56)$ & $224(40)$ & $21(4)$ & 557 & 4.6 \\
\hline Quebec & $134(47)$ & $147(52)$ & $4(1)$ & 285 & 3.8 \\
\hline Atlantic provinces & $79(63)$ & $33(26)$ & $14(11)$ & 126 & 5.4 \\
\hline Canada & $712^{*}(55)$ & $521(40)$ & $58(4)$ & $1291^{\dagger}$ & 4.1 \\
\hline
\end{tabular}

*Includes two general surgeons in the Yukon Territories; †Total physicians performing colonoscopies in Canada was less than the sum of providers in each province, because some physicians provided colonoscopy in more than one province.

of new endoscopists matches the need resulting from retirement and increased service demand.

The quality of endoscopy, especially colonoscopy, has gained significant attention (16). For example, variations in polyp detection rates, which are associated with the colonoscopy withdrawal technique, have highlighted variability in the quality of screening colonoscopies performed by individual endoscopists (17). Quality indicators for colonoscopy and other endoscopic procedures have been proposed, but are not routinely collected or reviewed. The quality with which a physician performs endoscopy will be influenced by initial training and ongoing maintenance of endoscopic skills (18-20).

Different groups of physicians who provide endoscopy in Canada undergo quite different training. Many subspecialists (gastroenterologists and colorectal surgeons) complete an accredited training program that includes extensive training and practical experience in endoscopy. Other specialists (general internists and general surgeons) may have a more limited endoscopy experience during their training. Finally, some physicians may have no endoscopic training during their postgraduate residency training, and learn endoscopy through informal training by colleagues and/or by attending short courses. Currently, there are no Canadian standards for credentialing in GI endoscopy.

In the present study, we only included physicians with an annual volume of at least 100 colonoscopies or gastroscopies, because it is believed that an adequate annual volume is required to maintain competence and expertise $(18,20)$. It is likely that there are additional providers who are performing fewer procedures each year. Schultz et al (21) reported that more than $25 \%$ of all physicians performing colonoscopy in Ontario between April 1, 2001 and March 31, 2002 performed less than 100 procedures. The quality of endoscopy provided by low-volume physicians is a concern. Hilsden (1) reported marked variability in polyp removal rates among low-volume colonoscopists in Alberta. Poor procedure quality may result in diminished effectiveness and increased complications.

In Canada, $53 \%$ of colonoscopies were performed by gastroenterologists. On average, the annual endoscopy volume for gastroenterologists exceeded that of general surgeons and other 
physician providers (although, based on our inclusion criteria, all providers performed more than 100 endoscopies). Unfortunately, given the nature of the available data, it is difficult to determine how different types of providers differ in their provision of GI endoscopy, apart from annual volume.

Our study did have some limitations. First, we were unable to distinguish between subspecialist and generalist physicians within the gastroenterologist and general surgeon categories. Therefore, it was not possible to identify regional variations in subspecialist providers. Second, because of privacy concerns, provinces with smaller numbers of providers were combined by CIHI before the data was provided to us. Third, we did not obtain data on endoscopists providing fewer than 100 procedures per year because we wanted to exclude those who only occasionally perform endoscopies.

\section{REFERENCES}

1. Hilsden RJ. Patterns of use of flexible sigmoidoscopy, colonoscopy and gastroscopy: A population-based study in a Canadian province. Can J Gastroenterol 2004;18:213-9.

2. Vinden C, Schultz S, Rabeneck L. ICES Research Atlas: Use of large bowel procedures in Ontario. Toronto: ICES, 2004.

3. Winawer S, Fletcher R, Rex D, et al, for the Gastrointestinal Cosortium Panel. Colorectal cancer screening and surveillance: Clinical guidelines and rationale - update based on new evidence. Gastroenterology 2003;124:544-60.

4. Leddin D. Canadian Association of Gastroenterology launches human resources planning initiatives. Can J Gastroenterol 2004;18:583-7.

5. National Physician Database: Data submission specifications manual, version 3.1. Ottawa: Canadian Institute for Health Information, 2003.

6. 2001 Census Dictionary. Statistics Canada Catalogue no. 92-378-XIE. Ottawa: Statistics Canada, 2002.

7. Full-time equivalent physicians report, Canada 2002-2003 and 2003-2004. Ottawa: Canadian Institute for Health Information, 2006.

8. Statistics Canada, Estimates of population by age and sex for Canada, Provinces and Territories. Statistics Canada, 2005. <http://www40.statcan.ca/101/cst01/demo02.htm?sdi=population> (Version current at September 1, 2006).

9. National Committee on Colorectal Cancer Screening. Recommendations for population-based colorectal cancer screening. Health Canada, 2003. < http://www.phac-aspc.gc.ca/ publicat/ncccs-cndcc/ccsrec_e.html $>$ (Version current at November 16, 2007).

10. Canadian Task Force on Preventive Health Care. Colorectal cancer screening. Recommendation statement from the Canadian Task Force on Preventive Health Care. CMAJ 2001;165:206-8.

11. Leddin D, Hunt R, Champion M, et al. Canadian Association of Gastroenterology and the Canadian Digestive Health Foundation: Guidelines on colon cancer screening. Can J Gastroenterol 2004;18:93-9.

\section{SUMMARY}

We have described the endoscopy workforce resources in Canada and have identified variations among provinces in these resources. This information will be useful in planning for the impact of colorectal cancer screening and the general growth in GI endoscopy that is needed because of population growth and aging. However, ensuring the provision of quality endoscopy will remain a challenge that needs to be addressed before the widespread adoption of colorectal cancer screening.

ACKNOWLEDGEMENTS: The authors wish to thank the executive and staff of the Canadian Association of Gastroenterology, particularly Sandra Daniels and Dr Des Leddin, for their support and assistance with this study.

12. Flanagan WM, Le Petit C, Berthelot JM, White KJ, Coombs BA, Jones-McLean E. Potential impact of population-based colorectal cancer screening in Canada. Chronic Dis Can 2003;24:81-8.

13. Moayyedi P, Tepper J, Hilsden R, Rabeneck L. International comparisons of manpower in gastroenterology. Am J Gastroenterol 2007;102:478-81.

14. Access to Digestive Health Care in Canada - I. Canadian Association of Gastroenterology, 2006. <http://www.waittimealliance.ca/ summaries/cag_summary.pdf> (Version current at November 27, 2007).

15. Canadian Medical Association. CMA Physician Resource Questionnaire 2003: Average hours worked per week by physicians by activity, broad specialty, and sex, 2003. <http://www.cma.ca/multimedia/ CMA/Content_Images/Inside_cma/Statistics/pwr-average1.pdf> (Version current at November 13, 2007).

16. Brotman M, Allen JI, Bickston SJ, et al, for the American Gastroenterological Association. AGA Task Force on Quality in Practice: A national overview and implications for GI practice. Gastroenterology 2005;129:361-9.

17. Rex DK. Colonoscopic withdrawal technique is associated with adenoma miss rates. Gastrointest Endosc 2000;51:33-6.

18. Position statement. Maintaining competency in endoscopic skills. American Society for Gastrointestinal Endoscopy. Gastrointest Endosc 1995;42:620-1.

19. Wexner SD, Litwin D, Cohen J, et al, for the American Society for Gastrointestinal Endoscopy, Society of American Gastrointestinal Endoscopic Surgeons, American Society of Colorectal Surgeons. Principles of privileging and credentialing for endoscopy and colonoscopy. Gastrointest Endosc 2002;55:145-8.

20. Wexner SD, Garbus JE, Singh JJ, for the SAGES Colonoscopy Study Outcomes Group. A prospective analysis of 13,580 colonoscopies. Reevaluation of credentialing guidelines. Surgical Endoscopy 2001;15:251-61.

21. Schultz SE, Vinden C, Rabeneck L. Colonoscopy and flexible sigmoidoscopy practice patterns in Ontario: A population-based study. Can J Gastroenterol 2007;21:431-4. 


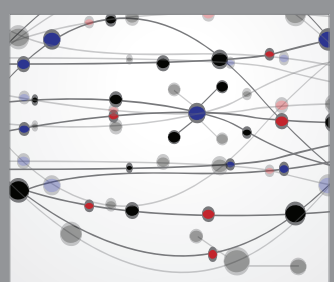

The Scientific World Journal
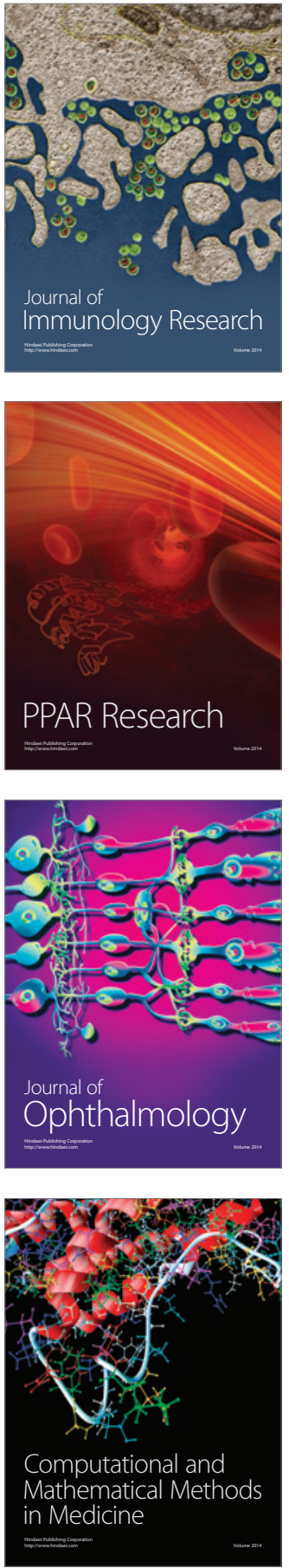

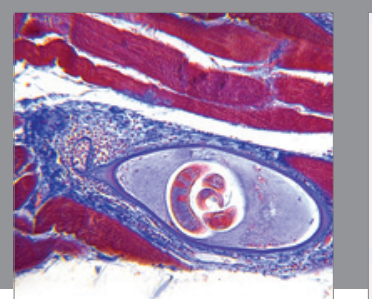

Gastroenterology Research and Practice

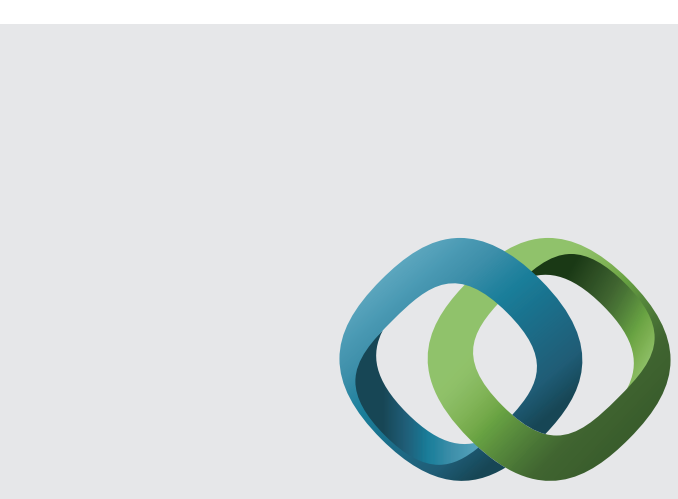

\section{Hindawi}

Submit your manuscripts at

http://www.hindawi.com
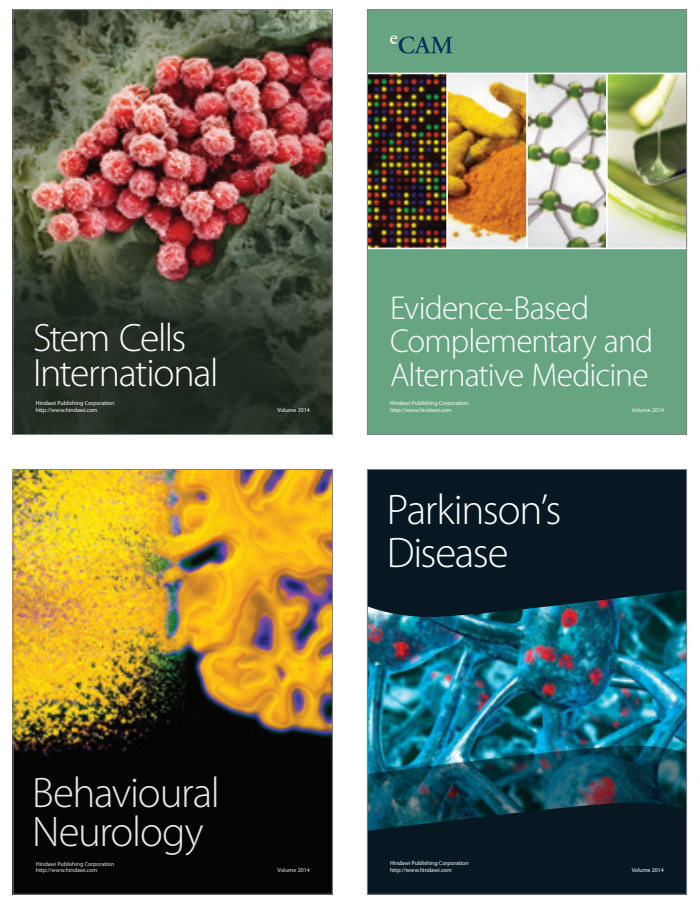
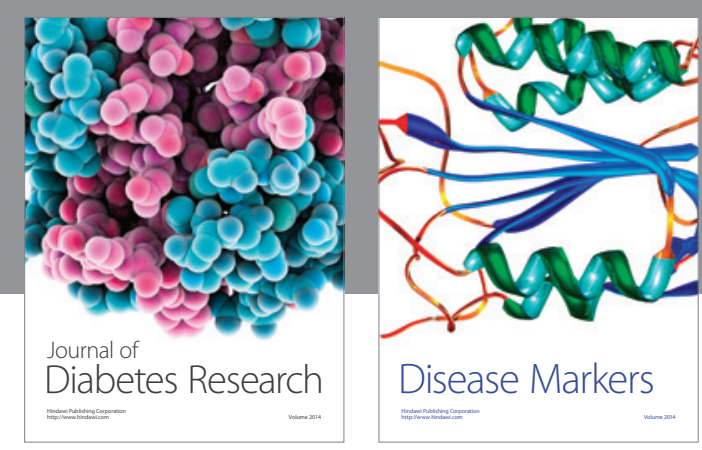

Disease Markers
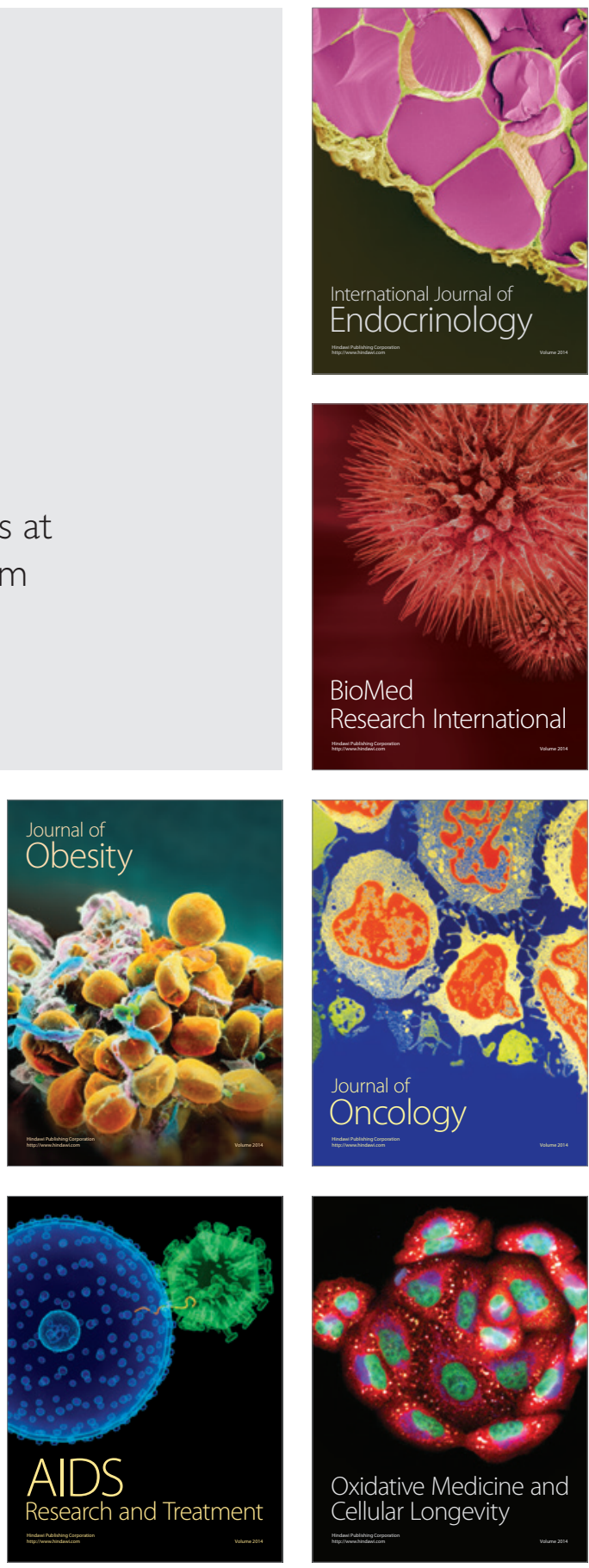